\title{
Soil Phosphorus Forms and Profile Distributions in the Tidal River Network Region in the Yellow River Delta Estuary
}

\author{
Junbao Yu, ${ }^{1}$ Fanzhu Qu, ${ }^{1,2}$ Huifeng Wu, ${ }^{1}$ Ling Meng, ${ }^{3}$ Siyao Du, ${ }^{3}$ and Baohua Xie ${ }^{1}$ \\ ${ }^{1}$ Key Laboratory of Coastal Environmental Processes and Ecological Remediation, Yantai Institute of Coastal Zone Research (YIC), \\ Chinese Academy of Sciences (CAS), Shandong Provincial Key Laboratory of Coastal Environmental Processes, YICCAS, \\ Yantai, Shandong 264003, China \\ ${ }^{2}$ University of Chinese Academy of Sciences, Beijing 100049, China \\ ${ }^{3}$ College of Environmental Science and Engineering, Ocean University of China, Qingdao, Shandong 266100, China
}

Correspondence should be addressed to Junbao Yu; junbao.yu@gmail.com

Received 21 February 2014; Revised 7 April 2014; Accepted 14 April 2014; Published 20 May 2014

Academic Editor: Xu Gang

Copyright (C) 2014 Junbao Yu et al. This is an open access article distributed under the Creative Commons Attribution License, which permits unrestricted use, distribution, and reproduction in any medium, provided the original work is properly cited.

Modified Hedley fraction method was used to study the forms and profile distribution in the tidal river network region subjected to rapid deposition and hydrologic disturbance in the Yellow River Delta (YRD) estuary, eastern China. The results showed that the total $\mathrm{P}\left(\mathrm{P}_{\mathrm{t}}\right)$ ranged from 612.1 to $657.8 \mathrm{mg} \mathrm{kg}^{-1}$. Dilute $\mathrm{HCl}$ extractable inorganic $\mathrm{P}\left(\mathrm{P}_{\mathrm{i}}\right)$ was the predominant form in all profiles, both as absolute values and as a percentage of total extracted $\mathrm{P}_{\mathrm{i}}$. The $\mathrm{NaOH}$ extractable organic $\mathrm{P}\left(\mathrm{P}_{\mathrm{o}}\right)$ was the predominant form of total extracted $\mathrm{P}_{\mathrm{o}}$, while Bicarb- $\mathrm{P}_{\mathrm{i}}$ and C.HCl- $\mathrm{P}_{\mathrm{o}}$ were the lowest fractions of total extracted $\mathrm{P}_{\mathrm{i}}$ and $\mathrm{P}_{\mathrm{o}}$ in all the $\mathrm{P}$ forms. The Resin$\mathrm{P}$ concentrations were high in the top soil layer and decreased with depth. The Pearson correlation matrix indicated that Resin-P, Bicarb- $\mathrm{P}_{\mathrm{i}}, \mathrm{NaOH}-\mathrm{P}_{\mathrm{i}}$, and C.HCl- $\mathrm{P}_{\mathrm{i}}$ were strongly positively correlated with salinity, TOC, $\mathrm{Ca}, \mathrm{Al}$, and Fe but negatively correlated with $\mathrm{pH}$. The significant correlation of any studied form of organic $\mathrm{P}$ (Bicarb- $\mathrm{P}_{\mathrm{o}}, \mathrm{NaOH}-\mathrm{P}_{\mathrm{o}}$, and C.HCl- $\mathrm{P}_{\mathrm{o}}$ ) with geochemical properties were not observed in the study. Duncan multiple-range test indicated that the $\mathrm{P}$ forms and distribution heterogeneity in the profiles could be attributed to the influences of vegetation cover and hydrologic disturbance.

\section{Introduction}

Phosphorus (P), as a limiting nutrient, is one of the major plant nutrient elements second in importance to nitrogen $(\mathrm{N})$ in terms of nutrient requirements for increased plant biomass production in ecosystem [1]. In its biogeochemical cycle, $\mathrm{P}$ is typically eroded from upland sources and transported, along with the sediment to which it is attached, to a final receiving water body $[2,3]$. Before reaching the ocean, overland flow and runoff may travel through most of tidal wetlands, which are complex, dynamic, and continually changing due to the action of wind, currents, tides, and waves. Phosphorus in tidal river network region typically exists in many complex chemical forms, while investigations of $\mathrm{P}$ biogeochemistry often partition the pool of $\mathrm{P}$ into its labile and refractory components, especially with regard to soil $\mathrm{P}$ availability for plant or phytoplankton growth [4].
Meanwhile, most methods for available $\mathrm{P}$ determination attempt to quantify $\mathrm{P}$ solubility using different extractions, but few of those were related to $\mathrm{P}$ supply rates and relevant to plant uptake $[5,6]$. To overcome this limitation, Hedley et al. [7] developed a method to extract P using a series of successively stronger reagents. At each step of the fractionation scheme, extracts could be assigned a role that could be used to characterize a chemical form of P. The sequential fractionation, in which the pool of soil $\mathrm{P}$ is partitioned into inorganic, organic, and microbial forms [8], can differentiate the plant-available forms (Resin- $\mathrm{P}_{\mathrm{i}}$, Bicarb- $\mathrm{P}_{\mathrm{i}}$, and Bicarb$\left.\mathrm{P}_{\mathrm{o}}\right)$ and refractory forms $\left(\mathrm{NaOH}-\mathrm{P}_{\mathrm{i}}, \mathrm{NaOH}-\mathrm{P}_{\mathrm{o}}\right.$, D.HCl- $\mathrm{P}_{\mathrm{i}}$, C.HCl- $\mathrm{P}_{\mathrm{i}}, \mathrm{C} . \mathrm{HCl}-\mathrm{P}_{\mathrm{o}}$, and Residual-P). Many previous studies have used the sequential fractionation scheme developed by Hedley, which was successfully used to separate forms of organically bound soil phosphorus from the geochemically 


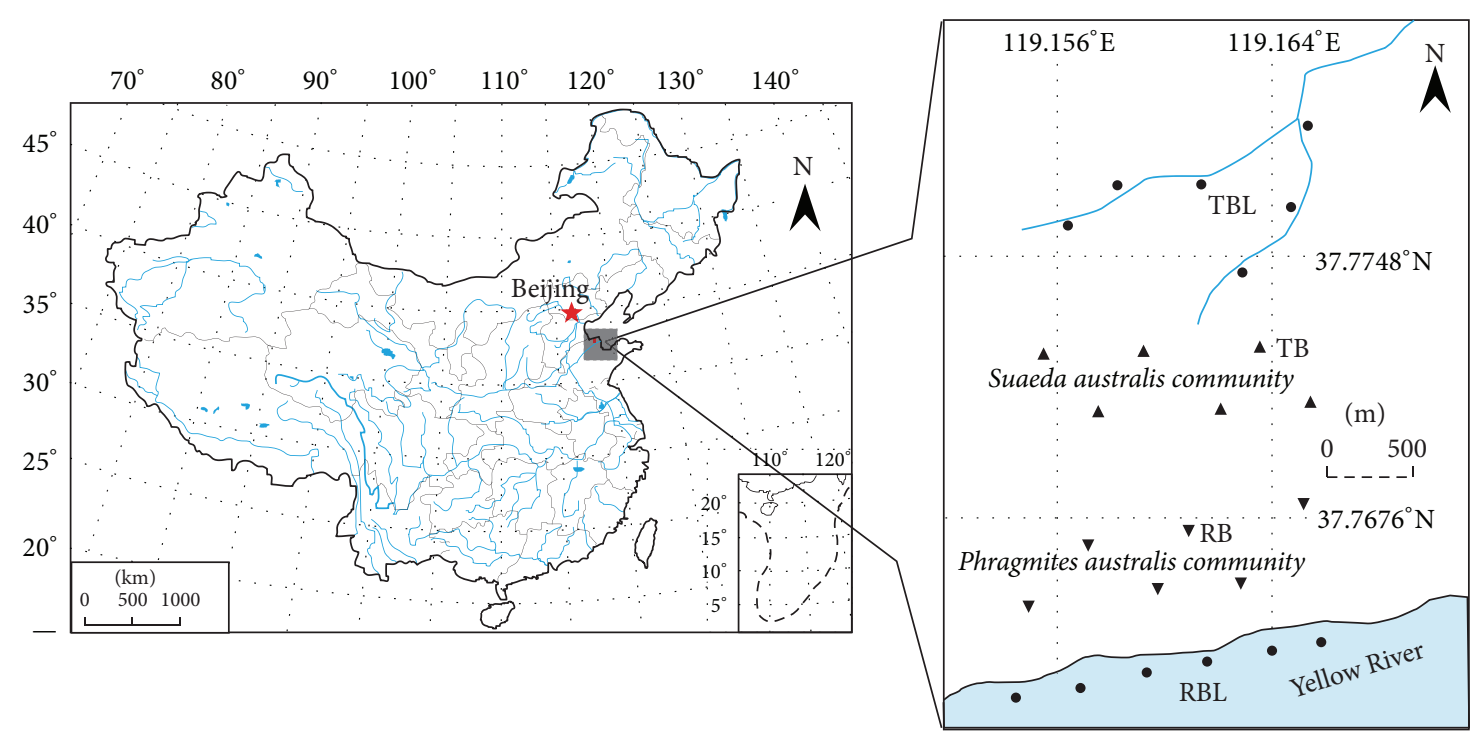

FIGURE 1: The tidal river network region in the Yellow River Delta estuary and sampling plots in wetlands (including bare river bed (BRB), river bank (RB), tidal bank (TB), and tidal creek bed (TCB)).

bound fractions [9], to successfully describe the contribution of biological processes to the concentrations and disposition of $\mathrm{P}$ pools across a gradient of mineral weathering and soil development [10]. Among the studies reviewed, there are rare systematic studies of sequentially extractable $\mathrm{P}$ fractions in the tidal river network soils reported and no concerned documentation of the relationship between $\mathrm{P}$ forms of tidal wetlands and their chemical soil properties is available, especially for the soils in the tidal river network region of the Yellow River Delta (YRD) estuary in the east part of China.

The Yellow River, whose basin was the birthplace of ancient Chinese civilization, is one of the essential rivers for China's very existence. The YRD is the youngest natural coastal wetland ecosystem and the most intensive land-ocean interaction region among the large river deltas in the world [11]. The typical characteristics of the YRD are rapid deposit and fast evolution because the sediment load delivered into the sea accounts for $6 \%$ of the global rivers' sediment load into the sea [12]. Thus the Yellow River is regarded as the largest contributor of fluvial sediment load compared to the oceans in the world. The net increase of delta shoreline length was $\sim 61.64 \mathrm{~km}$ with annual increase of $\sim 1.81 \mathrm{~km}$, and the net extension of area was $\sim 309.81 \mathrm{~km}^{2}$ with rate of $\sim 9.11 \mathrm{~km}^{2} \mathrm{yr}^{-1}$ within 34 years (1976-2009) [13].

The ability of wetlands to act as sinks for certain chemicals, sediments, and nutrients has been one of the main motivating factors for wetland protection. For the past few years, there are many studies focusing on the landscape pattern [14-16], biodiversity conservation [16], ecological restoration [17], and wetland evolution [11, 18] of the YRD. Unfortunately, few studies focused on the soil $\mathrm{P}$ forms and the relation of $\mathrm{P}$ distribution with vegetation cover and hydrologic disturbance in coastal areas [19-22]. In the present study, soil phosphorus forms and profile distributions in the tidal river network region were studied. Our objectives were (a) to fill a void of information on $\mathrm{P}$ forms of the tidal river network region soils, (b) to investigate the differences of contents and distribution of $\mathrm{P}$ forms of soils in river and tidal creek bed and bank by the sequential extraction procedure according to a modified Hedley fraction, (c) to correlate the content of $\mathrm{P}$ forms with basic chemical soil properties, and (d) to establish general differences in P forms and availability influence by vegetation cover and hydrologic disturbance.

\section{Material and Methods}

2.1. Study Area. The studied tidal river network region (Figure 1) is located in the Yellow River Delta Natural Reserve $\left(37^{\circ} 35^{\prime}-38^{\circ} 12^{\prime} \mathrm{N}, 118^{\circ} 33^{\prime}-119^{\circ} 20^{\prime} \mathrm{E}\right)$ established in 1992 by the State Council of China, which is between the Bohai Gulf and the Laizhou Bay in eastern China. As a wetland type reserve, which is well protected for the important habitat, breeding, or stopover place for the birds in China, it holds the most extensive, integrated, and youngest wetland ecosystem in the warm temperate zone of China. Due to deposition of lots of sand and mud carried by water of the Yellow River from the Loess Plateau, the main soil is typical saline alluvial soil (Fluvisols, FAO). The natural vegetation is salt-tolerant plants and aquatic plants. The predominant species in the tidal river network region are Phragmites australis and Suaeda heteroptera Kitag. This region is subjected to warm temperate continental monsoon climate with distinctive seasons and rainy summer. Average annual sunshine hours are 2590$2830 \mathrm{~h}$, average annual temperature is $11.7-12.8^{\circ} \mathrm{C}$, and the frost-free period is about $196 \mathrm{~d}$. The average annual precipitation is $530-630 \mathrm{~mm}$ with nearly $70 \%$ of the precipitation falling mainly in summer, while the evaporation is 1900$2400 \mathrm{~mm}$ and the drought index is up to 3.56 [17].

2.2. Soil Collection. In order to examine the forms and distribution of soil phosphorus in the tidal river network 
region in the YRD estuary, along the Yellow River and a tidal creek, four soil sampling plots were collected for study on 27 April in 2011. The plots were demonstrated as follows: (1) bare river bed (BRB), which was in the Yellow River bed with no vegetation cover; (2) river bank (RB), which was on the river bank with Phragmites australis as dominated species cover; (3) tidal bank (TB), which was on the tidal creek with Suaeda heteroptera Kitag. as dominated species cover; and (4) tidal creek bed (TCB), which was in the tidal creek bed with no vegetation cover. In each plot, 6 replicate soil samples were collected using a stainless-steel slide hammer with an inner diameter of $3.5 \mathrm{~cm}$. Each collected core was sectioned at $10 \mathrm{~cm}$ interval of $0-60 \mathrm{~cm}$ depth. The soil samples were stored immediately in polyethylene plastic bags after collection in the field. All soil samples were air-dried, grounded using a mortar and pestle, and then sieved $0.850 \mathrm{~mm}$ and $0.150 \mathrm{~mm}$ sieves prior to laboratory analysis.

\subsection{Laboratory Analyses and Statistical Methods. A $0.5000 \mathrm{~g}$} soil sample was placed in a $50 \mathrm{~mL}$ plastic centrifuge tube with $30 \mathrm{~mL}$ of deionized water and the freely exchangeable fractions were removed by anion exchange resin in the chloride form. The plant available and moderately labile pool was extracted with $\mathrm{NaHCO}_{3}(0.5 \mathrm{M}, \mathrm{pH}=8.5)$ and $0.1 \mathrm{M} \mathrm{NaOH}$, whereas $1 \mathrm{M} \mathrm{HCl}$ removed the Ca-associated portion, since $\mathrm{Fe}$ - or $\mathrm{Al}$-associated $\mathrm{P}$ that might remain unextracted after the $\mathrm{NaOH}$ extraction is insoluble in acid. Hot concentrated $\mathrm{HCl}$ was used to separate organic $\mathrm{P}$ $\left(\mathrm{P}_{\mathrm{o}}\right)$ from inorganic $\mathrm{P}\left(\mathrm{P}_{\mathrm{i}}\right)$ in stable residual fractions. The residue left after the hot concentrated $\mathrm{HCl}$ extraction is unlikely to contain anything but highly recalcitrant $\mathrm{P}_{\mathrm{i}}$ pool which can be digested with concentrated $\mathrm{H}_{2} \mathrm{SO}_{4}$ and $\mathrm{H}_{2} \mathrm{O}_{2}$ at $360^{\circ} \mathrm{C}$. To determine total $\mathrm{P}$ in $0.5 \mathrm{M} \mathrm{NaHCO}_{3}, 0.1 \mathrm{M}$ $\mathrm{NaOH}$, and concentrated $\mathrm{HCl}$, extracts of dissolved organic matter were oxidized with ammonium persulfate before $\mathrm{P}$ analysis. A volume of $5 \mathrm{~mL}$ of solution was injected into a $50 \mathrm{~mL}$ volumetric flask. $0.5 \mathrm{~g}$ ammonium persulfate and $10 \mathrm{~mL} 0.9 \mathrm{M} \mathrm{H}_{2} \mathrm{SO}_{4}$ were weighed into the flask containing $5 \mathrm{~mL}$ of the $\mathrm{NaHCO}_{3}$ and $\mathrm{NaOH}$ extracts. The extracts were then autoclaved for $60 \mathrm{~min}\left(\mathrm{NaHCO}_{3}\right.$ and concentrated $\left.\mathrm{HCl}\right)$ and $90 \mathrm{~min}(\mathrm{NaOH})$. Inorganic $\mathrm{P}$ in the $0.5 \mathrm{M} \mathrm{NaHCO}_{3}$ and $0.1 \mathrm{M} \mathrm{NaOH}$ extracts was determined by acidifying $10 \mathrm{~mL}$ aliquot in a $50 \mathrm{~mL}$ centrifuge tube with $6 \mathrm{~mL}$ and $1.6 \mathrm{~mL}$ of $0.9 \mathrm{M} \mathrm{H}_{2} \mathrm{SO}_{4}$ at $0^{\circ} \mathrm{C}$ for $30 \mathrm{~min}$ to precipitate $\mathrm{OM}$. The $\mathrm{OM}$ was removed by carefully decanting the supernatant after centrifuging at $16000 \mathrm{rpm}$ for $10 \mathrm{~min}$. Organic $\mathrm{P}$ was estimated as the difference between total $\mathrm{P}$ and $\mathrm{P}_{\mathrm{i}}$. The $\mathrm{P}$ concentration in the supernatant was determined by a Tu1810 spectrophotometer (PERSEE, China), using the ascorbic acid molybdenum blue method described by Murphy and Riley [23]. The P fractionation procedure has been described in detail by Tiessen and Moir [24].

To analyze for $\mathrm{pH}$, soil moisture (SM), soil salinity, and total organic carbon (TOC), the representative samples of dried and sieved soil were delivered to Yantai Institute of Coastal Zone Research, Chinese Academy of Sciences. Soil $\mathrm{pH}$ was measured with a Beckman $\mathrm{pH}$ meter with combination electrode (soil: water ratio $=1: 5$ ) and salinity was quantified with a conductivity bridge. Cutting ring and oven dry method was used to measure SM. TOC was measured using a LECO CN2000 combustion gas analyzer (AOAC International 1997). $\mathrm{Al}, \mathrm{Fe}$, and $\mathrm{Ca}$ in acid digested extract were measured by ICPS-7500 (Manufactured by Shimadzu, Japan).

The chemical analyses were performed at the Key Laboratory of Wetlands Ecology and Environment, Yantai Institute of Coastal Zone Research, Chinese Academy of Sciences. The $\mathrm{P}$ forms against concentrations of basic chemical properties and Duncan multiple-range test about $\mathrm{P}$ factions in the four plots were conducted using the Pearson correlation method. Correlation analyses and Duncan multiple-range test were conducted with SPSS 18.0 (SPSS, Inc. 2010).

\section{Results and Discussion}

3.1. General Characteristics of the Soils in the Tidal River Network Region. The mean $\mathrm{pH}$ of the tidal river network region soils which varied from 8.7 to 9.2 was strongly alkaline. The mean proportion of SM which ranged from 20.7 to $25.1 \%$ was high water content and the mean salinity which ranged from 0.4 to $22.2 \%$ was mainly hypersaline. Meanwhile, SM and salinity exhibited increasing gradients from the Yellow River bed to a tidal creek bed, which was primarily caused by the regionally geological, geochemical, and hydrologic conditions. The content of TOC ranged from 0.3 to $1.3 \%$ (Table 1), while the contents of $\mathrm{Ca}, \mathrm{Al}$, and $\mathrm{Fe}$ ranged 3.7$6.2 \%, 5.6-7.6 \%$, and $2.4-4.1 \%$, respectively (Table 1). Related research has also found that the soil characteristics in this region have low nutrients and high salinity [25]. These soils were characterized with low organic matter. Because the sediment to which they were attached in the YRD came from Loess Plateau by long transportation via the Yellow River, the organic matter was lost during the long transportation. These tidal river network region soils in the YRD estuary are classified as young hydromorphic alluvia (Fluvents) formed on fluvo-marine deposits. As a newborn estuarine coastal wetland, it was characterized by poor soil development with high soil salinity and low nutrient availability and only covered by salt-tolerant plant communities.

3.2. Distribution of Soil Phosphorus Fractions. Previous studies about the phosphorus fractions in an acid soil continuously fertilized with mineral and organic fertilizers revealed that the potential information about the distribution of soil $\mathrm{P}$ pools could help us to well understand the sinks and sources of $\mathrm{P}$ in the soil [26]. Related study has evaluated the mean total P fractions ranging from 471.1 to $694.9 \mathrm{mg} \mathrm{kg}^{-1}$ in the newly formed wetland soils in the Yellow River Delta [20]. In these soils in the tidal river network region, the mean content of total P $\left(\mathrm{P}_{\mathrm{t}}\right)$ was ranked as TCB (mean, $\left.657.8 \mathrm{mg} \mathrm{kg}^{-1}\right)>$ RB (mean, $649.2 \mathrm{mg} \mathrm{kg}^{-1}$ ) > TB (mean, $636.3 \mathrm{mg} \mathrm{kg}^{-1}$ ) 》 BRB (mean, $612.1 \mathrm{mg} \mathrm{kg}^{-1}$ ) (Table 2). The $\mathrm{P}_{\mathrm{t}}$ concentrations were larger in the top and bottom layers than those in the middle layers in all the soil profiles with an exception of BRB. The minimum value of $P_{t}$ occurred in $20-30 \mathrm{~cm}$ layer in $\mathrm{RB}$ and $\mathrm{TB}, 30-40 \mathrm{~cm}$ layer in TCB, but $50-60 \mathrm{~cm}$ layer 
TABLE 1: General characteristics of the soils in the tidal river network region.

\begin{tabular}{|c|c|c|c|c|c|c|c|c|}
\hline Soil & $\begin{array}{c}\text { Depth } \\
(\mathrm{cm})\end{array}$ & $\mathrm{pH}$ & SM (\%) & Salinity (\%) & TOC (\%) & $\mathrm{Ca}(\%)$ & $\mathrm{Al}(\%)$ & $\mathrm{Fe}(\%)$ \\
\hline \multirow{6}{*}{$\mathrm{BRB}$} & $0-10$ & $8.9(0.08)$ & $21.4(1.40)$ & $2.2(1.22)$ & $0.6(0.25)$ & $4.5(0.86)$ & $6.2(0.70)$ & $3.2(0.52)$ \\
\hline & $10-20$ & $9.1(0.05)$ & $21.1(0.19)$ & $0.7(0.22)$ & $0.5(0.13)$ & $4.3(0.31)$ & $6.3(0.33)$ & $2.8(0.22)$ \\
\hline & $20-30$ & $9.1(0.12)$ & $21.9(0.40)$ & $0.7(0.37)$ & $0.4(0.11)$ & $4.1(0.06)$ & $6.0(0.10)$ & $2.6(0.08)$ \\
\hline & $30-40$ & $9.2(0.07)$ & $22.6(0.36)$ & $0.5(0.24)$ & $0.3(0.05)$ & $4.0(0.05)$ & $5.8(0.14)$ & $2.5(0.10)$ \\
\hline & $40-50$ & $9.1(0.10)$ & $23.9(0.49)$ & $0.5(0.07)$ & $0.3(0.06)$ & $3.8(0.38)$ & $5.7(0.32)$ & $2.4(0.09)$ \\
\hline & $50-60$ & $9.2(0.07)$ & $24.5(0.45)$ & $0.4(0.03)$ & $0.3(0.09)$ & $3.7(0.39)$ & $5.6(0.35)$ & $2.5(0.05)$ \\
\hline \multirow{6}{*}{$\mathrm{RB}$} & $0-10$ & $8.8(0.28)$ & $21.0(1.83)$ & $4.4(4.32)$ & $1.2(0.18)$ & $4.9(0.50)$ & $6.7(0.46)$ & $3.2(0.46)$ \\
\hline & $10-20$ & $8.8(0.32)$ & $20.7(0.71)$ & $4.7(4.65)$ & $0.7(0.51)$ & $4.7(1.26)$ & $6.5(0.95)$ & $3.0(0.95)$ \\
\hline & $20-30$ & $8.7(0.24)$ & $21.3(0.83)$ & $4.9(3.92)$ & $0.7(0.19)$ & $4.4(0.53)$ & $6.3(0.36)$ & $2.8(0.42)$ \\
\hline & $30-40$ & $8.8(0.17)$ & $21.9(0.86)$ & $3.9(2.48)$ & $0.4(0.13)$ & $4.2(0.13)$ & $6.0(0.19)$ & $2.6(0.15)$ \\
\hline & $40-50$ & $8.8(0.14)$ & $22.2(0.70)$ & $4.9(2.51)$ & $0.9(0.66)$ & $5.2(1.54)$ & $6.8(0.94)$ & $3.2(0.82)$ \\
\hline & $50-60$ & $8.9(0.10)$ & $22.3(0.28)$ & $4.4(2.39)$ & $0.7(0.26)$ & $5.3(1.48)$ & $6.8(0.90)$ & $3.2(0.79)$ \\
\hline \multirow{6}{*}{$\mathrm{TB}$} & $0-10$ & $8.7(0.05)$ & $21.3(1.19)$ & $20.3(1.12)$ & $1.3(0.11)$ & $5.4(0.20)$ & $6.8(0.24)$ & $3.5(0.06)$ \\
\hline & $10-20$ & $8.9(0.13)$ & $21.7(0.88)$ & $9.6(0.81)$ & $1.0(0.36)$ & $5.6(0.51)$ & $6.9(0.20)$ & $3.7(0.57)$ \\
\hline & $20-30$ & $8.8(0.06)$ & $22.4(0.96)$ & $9.1(0.17)$ & $0.7(0.12)$ & $4.9(0.49)$ & $6.4(0.31)$ & $3.1(0.45)$ \\
\hline & $30-40$ & $8.8(0.10)$ & $23.0(0.79)$ & $9.4(2.72)$ & $0.7(0.12)$ & $4.9(0.55)$ & $6.5(0.61)$ & $3.2(0.40)$ \\
\hline & $40-50$ & $8.9(0.16)$ & $23.3(0.58)$ & $8.8(2.14)$ & $0.8(0.32)$ & $5.4(0.74)$ & $6.9(0.55)$ & $3.4(0.57)$ \\
\hline & $50-60$ & $8.9(0.08)$ & $24.4(0.38)$ & $7.9(0.59)$ & $0.9(0.53)$ & $5.0(0.22)$ & $6.6(0.14)$ & $3.2(0.12)$ \\
\hline \multirow{6}{*}{ TCB } & $0-10$ & $8.7(0.04)$ & $20.9(0.16)$ & $22.2(1.41)$ & $1.0(0.19)$ & $6.1(0.50)$ & $7.5(0.21)$ & $3.1(1.23)$ \\
\hline & $10-20$ & $8.8(0.10)$ & $21.5(0.56)$ & $11.7(1.50)$ & $1.2(0.13)$ & $6.2(0.41)$ & $7.6(0.29)$ & $4.1(0.36)$ \\
\hline & $20-30$ & $8.9(0.03)$ & $22.2(0.74)$ & $9.5(0.98)$ & $1.1(0.39)$ & $5.6(0.74)$ & $7.2(0.64)$ & $3.6(0.54)$ \\
\hline & $30-40$ & $8.8(0.10)$ & $24.0(0.32)$ & $14.7(5.90)$ & $0.9(0.23)$ & $5.9(0.56)$ & $7.4(0.53)$ & $3.9(0.36)$ \\
\hline & $40-50$ & $8.9(0.12)$ & $24.6(0.47)$ & $9.6(1.01)$ & $0.9(0.17)$ & $5.6(0.51)$ & $7.2(0.53)$ & $3.6(0.45)$ \\
\hline & $50-60$ & $8.8(0.06)$ & $25.1(0.63)$ & $10.0(1.95)$ & $0.8(0.22)$ & $5.5(0.92)$ & $7.2(0.78)$ & $3.6(0.66)$ \\
\hline
\end{tabular}

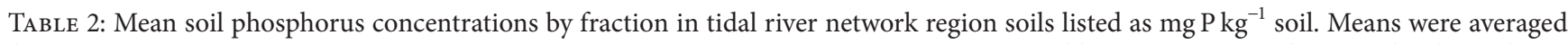
from 18 soil samples in each type. Duncan multiple-range test was conducted with 17 degrees of freedom. The signification of different forms of phosphorus was described in [8].

\begin{tabular}{|c|c|c|c|c|c|c|}
\hline P extract & BRB & $\mathrm{RB}$ & $\mathrm{TB}$ & TCB & Geochemical significance & Ecological significance \\
\hline Resin-P & $9.6^{c}$ & $11.0^{c}$ & $14.6^{\mathrm{b}}$ & $16.6^{\mathrm{a}}$ & \multirow{3}{*}{ Nonoccluded, rapid turnover } & Plant available \\
\hline Bicarb- $\mathrm{P}_{\mathrm{i}}$ & $4.2^{\mathrm{c}}$ & $4.9^{\mathrm{bc}}$ & $5.8^{\mathrm{b}}$ & $7.1^{\mathrm{a}}$ & & Easily plant available, \\
\hline Bicarb- $\mathrm{P}_{o}$ & $30.0^{\mathrm{b}}$ & $40.8^{\mathrm{a}}$ & $17.7^{\mathrm{c}}$ & $37.6^{\mathrm{a}}$ & & Easily mineralized \\
\hline $\mathrm{NaOH}-\mathrm{P}_{\mathrm{i}}$ & $4.0^{\mathrm{b}}$ & $5.4^{\mathrm{a}}$ & $5.7^{\mathrm{a}}$ & $6.2^{\mathrm{a}}$ & \multirow{2}{*}{ Nonoccluded, slow turnover } & Lesser plant available \\
\hline $\mathrm{NaOH}-\mathrm{P}_{\mathrm{o}}$ & $32.0^{\mathrm{b}}$ & $43.9^{\mathrm{a}}$ & $25.7^{\mathrm{bc}}$ & $22.1^{\mathrm{c}}$ & & \multirow{8}{*}{ Not directly plant available } \\
\hline D.HCl- $P_{i}$ & $420.2^{\mathrm{a}}$ & $417.4^{\mathrm{a}}$ & $423.5^{\mathrm{a}}$ & $414.6^{\mathrm{a}}$ & \multirow{7}{*}{ Occluded, slow turnover } & \\
\hline C.HCl- $\mathrm{P}_{\mathrm{i}}$ & $45.0^{\mathrm{c}}$ & $61.6^{\mathrm{b}}$ & $73.8^{\mathrm{a}}$ & $78.0^{\mathrm{a}}$ & & \\
\hline C.HCl-P & $30.1^{\mathrm{a}}$ & $22.0^{\mathrm{c}}$ & $22.7^{\mathrm{bc}}$ & $28.6^{\mathrm{ab}}$ & & \\
\hline Residual-P & $36.9^{c}$ & $42.0^{\mathrm{b}}$ & $46.9^{\mathrm{a}}$ & $47.1^{\mathrm{a}}$ & & \\
\hline $\mathrm{P}_{\mathrm{i}}$ & $520.0^{c}$ & $542.4^{\mathrm{b}}$ & $570.2^{\mathrm{a}}$ & $569.5^{\mathrm{a}}$ & & \\
\hline $\mathrm{P}_{\mathrm{o}}$ & $92.1^{\mathrm{b}}$ & $106.7^{\mathrm{a}}$ & $66.1^{\mathrm{c}}$ & $88.2^{\mathrm{b}}$ & & \\
\hline$P_{t}$ & $612.1^{c}$ & $649.2^{\mathrm{ab}}$ & $636.3^{\mathrm{b}}$ & $657.8^{\mathrm{a}}$ & & \\
\hline
\end{tabular}

The a, b, c represent significant differences between means for groups, while means for groups in homogeneous subsets are displayed as ab and bc $(P=0.05, n=$ 18). 
BRB

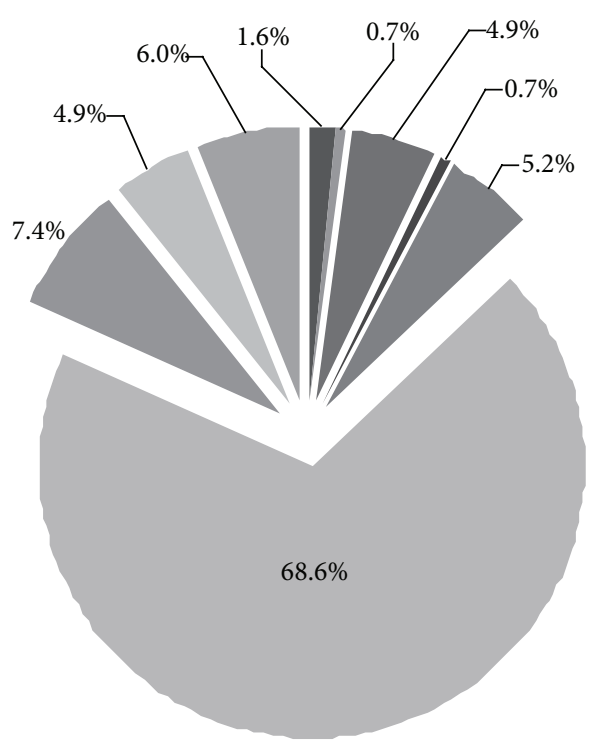

TB

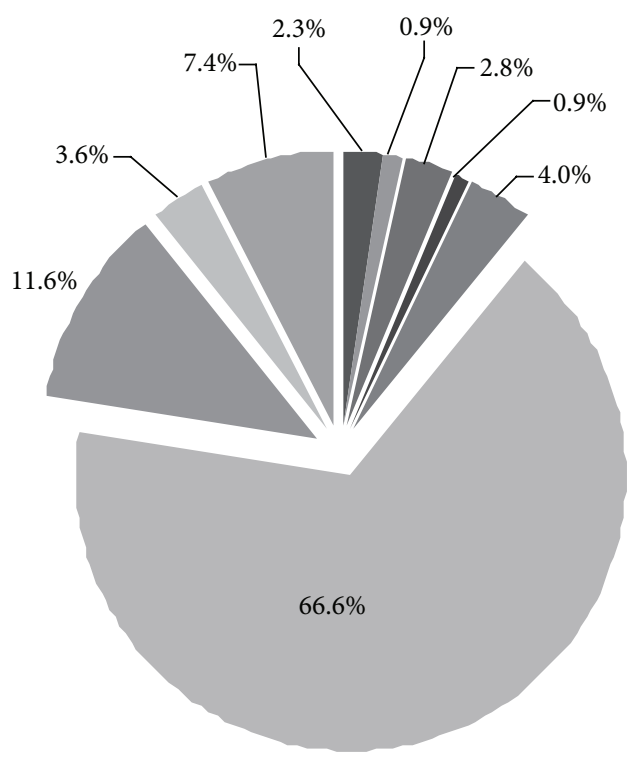

Resin- $\mathrm{P}_{\mathrm{i}}$

D.HCl- $\mathrm{P}_{\mathrm{i}}$
Bicarb- $\mathrm{P}_{\mathrm{i}}$

C.HCl- $\mathrm{P}_{\mathrm{i}}$

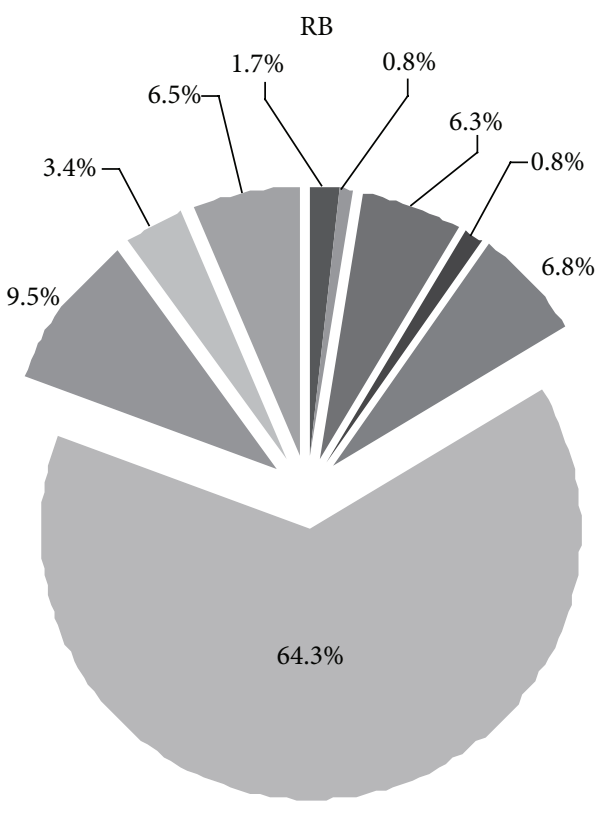

TCB
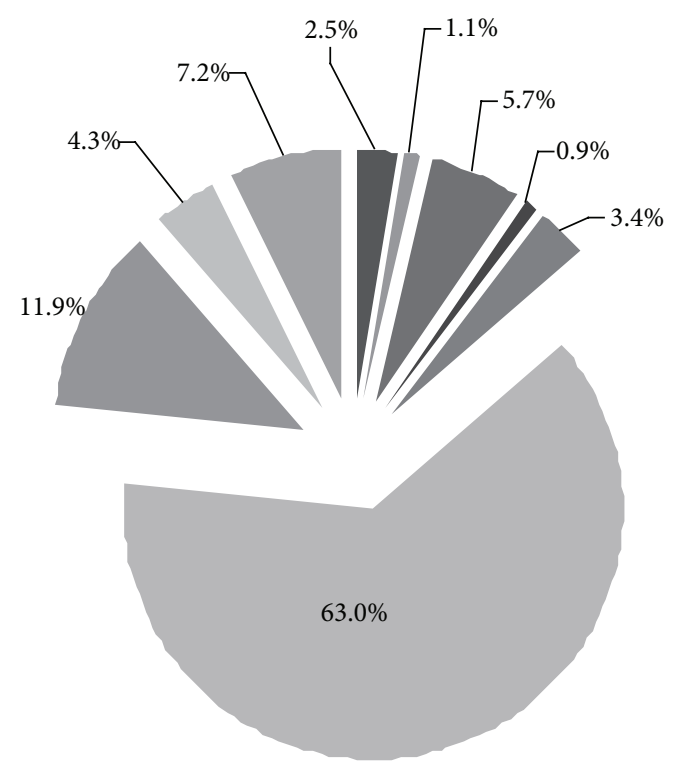

$\mathrm{NaOH}-\mathrm{P}$

Residual- $\mathrm{P}_{\mathrm{i}}$

Figure 2: Soil $\mathrm{P}$ fractions in BRB, RB, TB, and TCB soils ( $\mathrm{P}$ fractions including Resin-P, Bicarb- $\mathrm{P}_{\mathrm{i}}, \mathrm{NaOH}-\mathrm{P}_{\mathrm{i}}$, D.HCl- $\mathrm{P}_{\mathrm{i}}$, C.HCl- $\mathrm{P}_{\mathrm{i}}$, Bicarb- $\mathrm{P}_{\mathrm{o}}$, $\mathrm{NaOH}-\mathrm{P}_{\mathrm{o}}$, C.HCl- $\mathrm{P}_{\mathrm{o}}$, and Residual-P).

in BRB (Table 3 and Figure 3). Duncan multiple-range test indicated a marked difference among TCB, TB, and BRB, while the differences between TCB and RB, TB and RB were not significant (Table 2). The mean content of inorganic $\mathrm{P}$ forms with Resin-P, Bicarb- $\mathrm{P}_{i}, \mathrm{NaOH}-\mathrm{P}_{\mathrm{i}}$, D.HCl- $\mathrm{P}_{\mathrm{i}}$, C.HCl$\mathrm{P}_{\mathrm{i}}$, and Residual-P (recalcitrant $\mathrm{P}_{\mathrm{i}}$ ) ranged 9.6-16.6, 4.27.1, 4.0-6.2, 414.6-423.5, 45.0-78.0, and 36.9-47.1 $\mathrm{mg} \mathrm{kg}^{-1}$, respectively (Table 2 ) while the mean content of organic $\mathrm{P}$ forms with Bicarb- $\mathrm{P}_{\mathrm{o}}, \mathrm{NaOH}-\mathrm{P}_{\mathrm{o}}$, and C.HCl- $\mathrm{P}_{\mathrm{o}}$ ranged $30.0-$ $40.8,22.1-43.9$, and $22.0-30.1 \mathrm{mg} \mathrm{kg}^{-1}$, respectively (Table 2). In all the soils, total inorganic $\mathrm{P}$ was the predominant part and accounted for 82.7-90.9\%.

The plant available $\mathrm{P}$ fractions-Resin $\mathrm{P}$ and Bicarb$\mathrm{P}_{\mathrm{i}} / \mathrm{P}_{\mathrm{O}}$ - summed to $7.2 \%$ of total $\mathrm{P}$ in the $\mathrm{BRB}$ and $8.8 \%$ in the $\mathrm{RB}$, meanwhile $6.0 \%$ of total $\mathrm{P}$ in the $\mathrm{TB}$ and $9.3 \%$ in the TB (Table 2). Resin-P is reasonably well defined as freely 

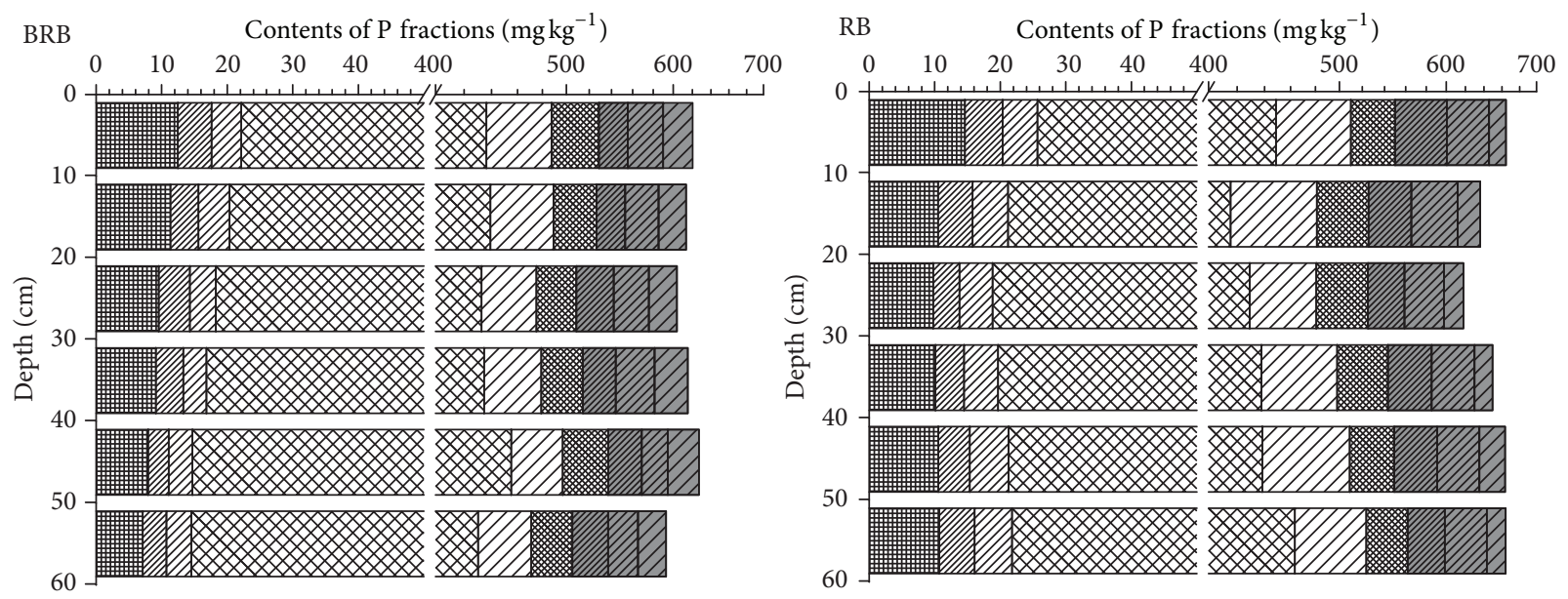

TB Contents of $\mathrm{P}$ fractions $\left(\mathrm{mg} \mathrm{kg}^{-1}\right)$

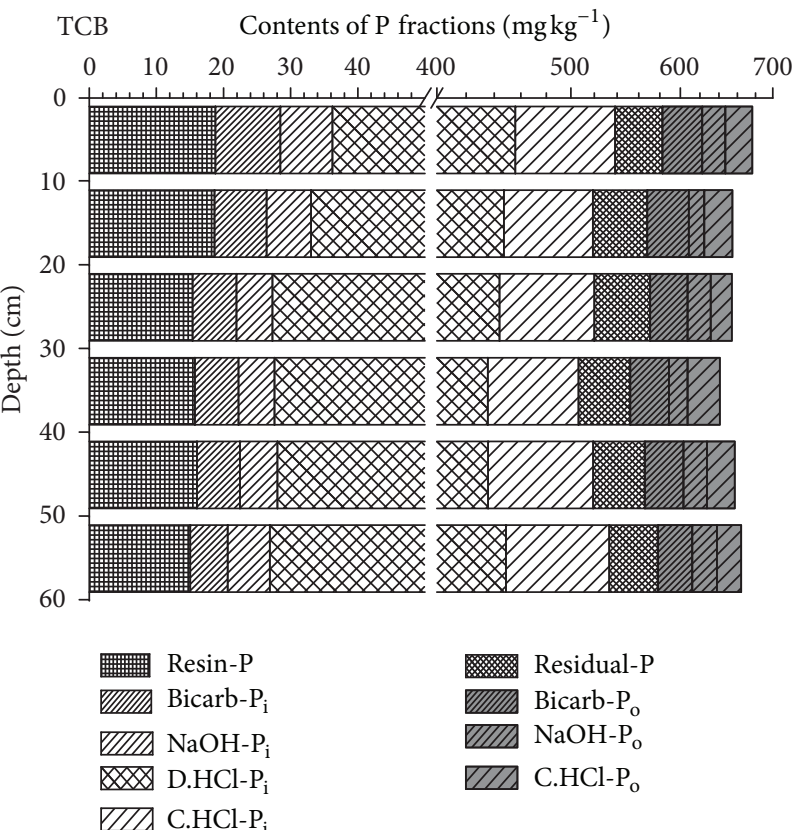

Figure 3: $\mathrm{P}$ fractions distribution in BRB, RB, TB, and TCB soil profiles ( $\mathrm{P}$ forms including Resin-P, Bicarb- $\mathrm{P}_{\mathrm{i}}, \mathrm{NaOH}-\mathrm{P}_{\mathrm{i}}, \mathrm{D} . \mathrm{HCl}-\mathrm{P}_{\mathrm{i}}, \mathrm{C} . \mathrm{HCl}-\mathrm{P}_{\mathrm{i}}$, Bicarb- $\mathrm{P}_{\mathrm{o}}, \mathrm{NaOH}-\mathrm{P}_{\mathrm{o}}, \mathrm{C} . \mathrm{HCl}-\mathrm{P}_{\mathrm{o}}$, and Residual-P).

exchangeable $\mathrm{P}_{\mathrm{i}}$, since the resin extract does not chemically modify the soil solution. The mean content of Resin-P was ranked as TCB (16.6 $\left.\mathrm{mg} \mathrm{kg}^{-1}, 2.5 \%\right) \gg \mathrm{TB}\left(14.6 \mathrm{mg} \mathrm{kg}^{-1}\right.$, $2.3 \%) \gg \mathrm{RB}\left(11.0 \mathrm{mg} \mathrm{kg}^{-1}, 1.7 \%\right)>\mathrm{BRB}\left(9.6 \mathrm{mg} \mathrm{kg}^{-1}, 1.6 \%\right)$ (Table 2 and Figure 2). In all profiles, the Resin-P concentrations were high in the top soil layer and decreased with depth (Table 3 and Figure 3 ). The most likely contributor to the effect of exchanging on Resin-P in the tidal river network region was salinity, which was an important feature of coastal wetlands that can affect $P$ sorption.

Bicarbonate extracts a $\mathrm{P}_{\mathrm{i}}$ fraction, which is likely to be plant available, since the chemical changes introduced are minor and somewhat representative of root action respiration. Bicarb- $\mathrm{P}_{\mathrm{o}}$, which is easily mineralisable, is also likely to represent similar pools. The mean content of Bicarb- $\mathrm{P}_{\mathrm{i}}$ which was ranked as TCB $\left(7.1 \mathrm{mg} \mathrm{kg}^{-1} \mathrm{~g}, 1.1 \%\right) \gg$
$\mathrm{TB}\left(5.8 \mathrm{mg} \mathrm{kg}^{-1}, 0.9 \%\right)>\mathrm{RB}\left(4.9 \mathrm{mg} \mathrm{kg}^{-1}, 0.8 \%\right)>\mathrm{BRB}$ $\left(4.2 \mathrm{mg} \mathrm{kg}^{-1}, 0.7 \%\right)$ (Table 2 and Figure 2) was the lowest fraction of total extracted $\mathrm{P}_{\mathrm{i}}$. The mean contents of Bicarb$\mathrm{P}_{\mathrm{o}}$ of TB, BRB, TCB, and RB were $17.7 \mathrm{mg} \mathrm{kg}^{-1}, 30.0 \mathrm{mg} \mathrm{kg}^{-1}$, $37.6 \mathrm{mg} \mathrm{kg}^{-1}$, and $40.8 \mathrm{mg} \mathrm{kg}^{-1}$, respectively, in soil profiles. Suaeda heteroptera Kitag., as pioneer plant community in TB in newly from coastal wetland, significantly enhanced the easily mineralisable $\mathrm{P}_{\mathrm{o}}$ and increased $\mathrm{P}$ availability.

$\mathrm{NaOH}$ extractable $\mathrm{P}\left(\mathrm{NaOH}-\mathrm{P}_{\mathrm{i}}+\mathrm{NaOH}-\mathrm{P}_{\mathrm{o}}\right)$ in the soil profiles averaged $36.0 \mathrm{mg} \mathrm{kg}^{-1}$ in BRB soils, $49.3 \mathrm{mg} \mathrm{kg}^{-1}$ in $\mathrm{RB}$ soils, $31.4 \mathrm{mg} \mathrm{kg}^{-1}$ in TB soils, and $28.36 \mathrm{mg} \mathrm{kg}^{-1}$ in TCB soils (Table 2). NaOH- $\mathrm{P}_{\mathrm{o}}$ (mean: $3.4-6.8 \%$ of $\mathrm{P}_{\mathrm{t}}$ ) was the predominant form of total extracted $\mathrm{P}_{\mathrm{o}}$ (Figure 2). The depth distribution of Bicarb- $\mathrm{P}_{i}$ and $\mathrm{NaOH}-\mathrm{P}_{i}$ in $\mathrm{BRB}, \mathrm{TB}$, and TCB was large in top soil and decreased with depth. The distributions in $\mathrm{RB}$ profiles showed that 
TABle 3: Mean content $\left(\mathrm{mg} \mathrm{kg}^{-1}\right)$ of $\mathrm{P}$ forms of the tidal river network region soil profiles in the Yellow River Delta estuary.

\begin{tabular}{|c|c|c|c|c|c|c|c|c|c|c|c|c|c|}
\hline Soil & $\begin{array}{l}\text { Depth } \\
(\mathrm{cm})\end{array}$ & Resin-P & Bicarb- $\mathrm{P}_{\mathrm{i}}$ & $\mathrm{NaOH}-\mathrm{P}_{\mathrm{i}}$ & D.HCl-P ${ }_{i}$ & C.HCl-P ${ }_{i}$ & Residual-P & Bicarb- $\mathrm{P}_{\mathrm{o}}$ & $\mathrm{NaOH}-\mathrm{P}_{\mathrm{o}}$ & C.HCl-P & $\mathrm{P}_{\mathrm{i}}$ & $\mathrm{P}_{\mathrm{o}}$ & $P_{t}$ \\
\hline \multirow{6}{*}{ BRB } & $0-10$ & 12.5 & 5.2 & 4.5 & 414.1 & 51.3 & 41.0 & 26.6 & 34.9 & 30.4 & 528.6 & 102.5 & 620.5 \\
\hline & $10-20$ & 11.3 & 4.3 & 4.8 & 418.8 & 50.0 & 37.1 & 26.5 & 32.6 & 27.9 & 526.2 & 96.2 & 613.3 \\
\hline & $20-30$ & 9.5 & 4.7 & 4.0 & 414.5 & 42.4 & 33.4 & 33.7 & 33.5 & 28.2 & 508.6 & 100.6 & 604.0 \\
\hline & $30-40$ & 9.1 & 4.2 & 3.6 & 417.7 & 44.5 & 35.4 & 29.6 & 37.2 & 33.9 & 514.5 & 102.2 & 615.1 \\
\hline & $40-50$ & 7.9 & 3.1 & 3.6 & 440.5 & 41.8 & 39.9 & 31.9 & 25.7 & 32.5 & 536.9 & 97.5 & 627.1 \\
\hline & $50-60$ & 7.1 & 3.6 & 3.8 & 415.5 & 40.8 & 34.3 & 31.8 & 28.3 & 27.6 & 505.1 & 94.4 & 592.9 \\
\hline \multirow{6}{*}{$\mathrm{RB}$} & $0-10$ & 14.6 & 5.8 & 5.3 & 423.1 & 61.1 & 40.2 & 50.6 & 44.9 & 19.0 & 550.0 & 135.7 & 664.5 \\
\hline & $10-20$ & 10.5 & 5.3 & 5.4 & 394.1 & 65.9 & 44.5 & 39.8 & 46.5 & 23.8 & 525.7 & 130.8 & 635.8 \\
\hline & $20-30$ & 9.8 & 4.0 & 5.0 & 410.2 & 51.6 & 44.5 & 33.7 & 38.9 & 20.3 & 525.1 & 117.1 & 618.0 \\
\hline & $30-40$ & 10.1 & 4.4 & 5.2 & 418.2 & 60.4 & 44.9 & 42.1 & 44.4 & 19.7 & 543.1 & 131.4 & 649.3 \\
\hline & $40-50$ & 10.5 & 4.8 & 5.9 & 417.1 & 70.6 & 40.1 & 41.8 & 44.3 & 28.2 & 549.0 & 126.1 & 663.3 \\
\hline & $50-60$ & 10.7 & 5.4 & 5.7 & 441.6 & 60.2 & 38.2 & 37.0 & 44.4 & 21.0 & 561.8 & 119.5 & 664.1 \\
\hline \multirow{6}{*}{$\mathrm{TB}$} & $0-10$ & 18.4 & 8.2 & 7.5 & 421.9 & 78.7 & 46.4 & 20.7 & 26.6 & 26.4 & 581.1 & 93.7 & 654.8 \\
\hline & $10-20$ & 15.6 & 6.5 & 5.9 & 420.6 & 71.8 & 46.7 & 16.8 & 27.2 & 21.6 & 567.1 & 90.7 & 632.7 \\
\hline & $20-30$ & 12.8 & 4.5 & 5.1 & 420.5 & 67.2 & 46.3 & 14.1 & 22.7 & 19.1 & 556.4 & 83.1 & 612.4 \\
\hline & $30-40$ & 14.2 & 5.1 & 5.2 & 424.8 & 70.7 & 50.4 & 18.7 & 25.9 & 20.1 & 570.4 & 95.0 & 635.1 \\
\hline & $40-50$ & 14.5 & 5.4 & 5.3 & 420.8 & 83.5 & 50.8 & 20.5 & 25.8 & 28.3 & 580.3 & 97.0 & 654.9 \\
\hline & $50-60$ & 12.1 & 5.0 & 5.2 & 432.4 & 70.6 & 40.6 & 15.2 & 26.0 & 20.7 & 565.8 & 81.8 & 627.8 \\
\hline \multirow{6}{*}{ TCB } & $0-10$ & 18.8 & 9.7 & 7.7 & 419.6 & 82.4 & 44.3 & 40.1 & 24.3 & 29.7 & 582.5 & 108.6 & 676.5 \\
\hline & $10-20$ & 18.7 & 7.7 & 6.6 & 414.2 & 71.3 & 49.3 & 40.6 & 15.9 & 30.1 & 567.9 & 105.8 & 654.5 \\
\hline & $20-30$ & 15.4 & 6.5 & 5.4 & 416.7 & 75.9 & 50.9 & 36.5 & 24.0 & 22.5 & 570.8 & 111.4 & 653.8 \\
\hline & $30-40$ & 15.8 & 6.5 & 5.4 & 407.7 & 71.1 & 45.6 & 36.8 & 18.7 & 33.4 & 552.0 & 101.2 & 640.9 \\
\hline & $40-50$ & 16.0 & 6.4 & 5.6 & 407.6 & 83.2 & 47.0 & 37.5 & 23.9 & 29.7 & 565.8 & 108.4 & 656.9 \\
\hline & $50-60$ & 15.0 & 5.6 & 6.2 & 421.9 & 84.2 & 45.3 & 33.8 & 25.8 & 26.1 & 578.3 & 104.9 & 664.0 \\
\hline
\end{tabular}

the low concentration of Bicarb- $\mathrm{P}_{\mathrm{i}}$ was encountered at $20-30 \mathrm{~cm}$ depth and the high concentration of $\mathrm{NaOH}-$ $\mathrm{P}_{\mathrm{i}}$ was encountered at $50-60 \mathrm{~cm}$ depth of the soil (Table 3 and Figure 3). Meanwhile, we did not observe vertical variation trends of Bicarb- $\mathrm{P}_{\mathrm{o}}$ and $\mathrm{NaOH}-\mathrm{P}_{\mathrm{o}}$ and marked differences in the same profile were not shown.

Dilute $\mathrm{HCl}$ extractable inorganic $\mathrm{P}$ (D.HCl- $\mathrm{P}_{\mathrm{i}}$ ) (mean: $63.0-68.6 \%$ of $\mathrm{P}_{t}$ ) was the predominant form in all profiles, both as absolute values and as a percentage of total extracted $\mathrm{P}_{\mathrm{i}}$. Dilute $\mathrm{HCl}$ extractable $\mathrm{P}$ was clearly defined as inorganic $\mathrm{P}$ associated with $\mathrm{Ca}[5]$. There were no significant vertical differences with respect to the soil D.HCl- $\mathrm{P}_{\mathrm{i}}$ profiles in all the four profiles (Figure 3 ). The D.HCl- $\mathrm{P}_{\mathrm{i}}$ is the predominant form (mean: $394.1-441.6 \mathrm{mg} \mathrm{kg}^{-1} ; 63.0 \%-68.6 \%$ ), both as absolute values and as a percentage of total extracted $\mathrm{P}$, which suggests that a relatively high proportion of inorganic $\mathrm{P}$ is in no-directly plant available forms. The depth distribution of D.HCl- $\mathrm{P}_{\mathrm{i}}$ in all profiles showed little differences in top soil and dramatically increased in bottom soil. The maximum content of D.HCl- $P_{i}$ in RB, TB, and TCB occurred in 50$60 \mathrm{~cm}$ layer and in $40-50 \mathrm{~cm}$ layer in BRB profile (Table 3 ).

The hot concentrated $\mathrm{HCl}$ extractable $\mathrm{P}_{\mathrm{i}}$ (C.HCl$\mathrm{P}_{\mathrm{i}}$ ) and Residual-P were ranked as TCB (78.0 $\mathrm{mg} \mathrm{kg}^{-1}$, $11.9 \%$, and $\left.47.1 \mathrm{mg} \mathrm{kg}^{-1}, 7.2 \%\right)>\mathrm{TB}\left(73.8 \mathrm{mg} \mathrm{kg}^{-1}, 11.6 \%\right.$, and $\left.46.9 \mathrm{mg} \mathrm{kg}^{-1}, 7.4 \%\right) \gg \mathrm{RB}\left(61.6 \mathrm{mg} \mathrm{kg}^{-1}, 9.5 \%\right.$, and $\left.42.0 \mathrm{mg} \mathrm{kg}^{-1}, 6.5 \%\right)>\mathrm{BRB} \quad\left(45.0 \mathrm{mg} \mathrm{kg}^{-1}, 7.4 \%\right.$, and $36.9 \mathrm{mg} \mathrm{kg}^{-1}, 6.0 \%$ ) (Table 2 and Figure 2). Meanwhile, the content of the hot concentrated $\mathrm{HCl}$ extractable $\mathrm{P}_{\mathrm{o}}$ (C.HCl- $\mathrm{P}_{\mathrm{o}}$, mean: 3.4-4.9\%), which was the lowest fraction of total extracted $\mathrm{P}_{\mathrm{o}}$ in all the $\mathrm{P}$ forms, was ranked as $\mathrm{BRB}\left(30.1 \mathrm{mg} \mathrm{kg}^{-1}, 4.9 \%\right)>\mathrm{TCB}\left(28.6 \mathrm{mg} \mathrm{kg}^{-1}, 4.3 \%\right)$ $\gg \mathrm{TB}\left(22.7 \mathrm{mg} \mathrm{kg}^{-1}, 3.6 \%\right)>\mathrm{RB}\left(22.0 \mathrm{mg} \mathrm{kg}^{-1}, 3.4 \%\right)$ (Table 2 and Figure 2). Meanwhile, there were no significant vertical differences with respect to the soil C. $\mathrm{HCl}-\mathrm{P}_{\mathrm{i}} / \mathrm{P}_{\mathrm{o}}$ and Residual-P profiles (Figure 3).

3.3. Phosphorus Forms Related to Soil Geochemical Properties. The correlation analysis results showed that the Resin-P, Bicarb- $\mathrm{P}_{\mathrm{i}}, \mathrm{OH}-\mathrm{P}_{\mathrm{i}}$, and C.HCl- $\mathrm{P}_{\mathrm{i}}$ were strongly positively correlated with salinity $(r=0.76,0.69,0.61$, and 0.64 , resp. $)$, TOC $(r=0.63,0.65,0.62$, and 0.58 , resp. $), \mathrm{Ca}(r=0.75,0.74$, 0.60 , and 0.72 , resp.), $\mathrm{Al}(r=0.75,0.71,0.54$, and 0.73 , resp.), and Fe ( $r=0.65,0.63,0.48$, and 0.63 , resp.) but negatively correlated with $\mathrm{pH}(r=0.48,0.45,0.60$, and 0.50 , resp.) (Table 4 ). The availability of $\mathrm{P}$ in most ecosystems depends on soil properties that regulate $\mathrm{P}$ availability, such as mineralogy of the parent material, leaching rates, and soil texture [27]. Part of the reason for the observed correlations might be that, 
TABLE 4: Pearson correlation coefficients between P fractions and soil geochemical properties.

\begin{tabular}{|c|c|c|c|c|c|c|c|c|c|c|}
\hline \multirow{2}{*}{ Sites } & & \multicolumn{9}{|c|}{ Pearson correlation } \\
\hline & & Resin-P & Bicarb- $\mathrm{P}_{\mathrm{i}}$ & $\mathrm{NaOH}-\mathrm{P}_{\mathrm{i}}$ & D.HCl-P ${ }_{i}$ & C.HCl- $\mathrm{P}_{\mathrm{i}}$ & Bicarb- $\mathrm{P}_{\mathrm{o}}$ & $\mathrm{NaOH}-\mathrm{P}_{\mathrm{o}}$ & C.HCl- $\mathrm{P}_{\mathrm{o}}$ & Residual-P \\
\hline \multirow{7}{*}{$\begin{array}{l}\mathrm{BRB} \\
(n=18)\end{array}$} & $\mathrm{pH}$ & $-0.66^{* *}$ & & & & & & & & \\
\hline & $\mathrm{SM}$ & $-0.77^{* *}$ & & & & & & & & \\
\hline & Salinity & $0.50^{*}$ & & & & & & & & \\
\hline & TOC & $0.59^{*}$ & $0.64^{* *}$ & & & & & & & \\
\hline & $\mathrm{Ca}$ & $0.65^{* *}$ & & & & $0.78^{* *}$ & & & & \\
\hline & $\mathrm{Al}$ & $0.59^{*}$ & & & & $0.74^{* *}$ & & & & \\
\hline & $\mathrm{Fe}$ & $0.73^{* *}$ & $0.56^{*}$ & & & $0.76^{* *}$ & & & & \\
\hline \multirow{7}{*}{$\begin{array}{l}\mathrm{RB} \\
(n=18)\end{array}$} & $\mathrm{pH}$ & & & $-0.66^{* *}$ & & & & $0.61^{* *}$ & $-0.58^{*}$ & $-0.58^{*}$ \\
\hline & SM & $-0.47^{*}$ & $-0.49^{* *}$ & & & & & & & \\
\hline & Salinity & & $0.54^{* *}$ & & & & & & $0.55^{*}$ & \\
\hline & TOC & $0.59^{*}$ & $0.75^{* *}$ & $0.61^{* *}$ & & & & & & \\
\hline & $\mathrm{Ca}$ & $0.48^{*}$ & $0.79^{* *}$ & $0.76^{* *}$ & & $0.55^{* *}$ & & & $0.48^{*}$ & \\
\hline & $\mathrm{Al}$ & $0.54^{*}$ & $0.83^{* *}$ & $0.73^{* *}$ & & $0.53^{* *}$ & & & $0.49^{*}$ & \\
\hline & $\mathrm{Fe}$ & $0.59^{*}$ & $0.86^{* *}$ & $0.73^{* *}$ & & $0.51^{* *}$ & & & $0.50^{*}$ & \\
\hline \multirow{7}{*}{$\begin{array}{l}\mathrm{TB} \\
(n=18)\end{array}$} & $\mathrm{pH}$ & & & & & & & & & \\
\hline & SM & & & $-0.54^{* *}$ & & & & & & \\
\hline & Salinity & $0.53^{*}$ & $0.60^{* *}$ & $0.77^{* *}$ & & & & & & \\
\hline & TOC & $0.45^{*}$ & $0.60^{* *}$ & $0.66^{* *}$ & & & & & & \\
\hline & $\mathrm{Ca}$ & $0.59^{* *}$ & $0.71^{* *}$ & & & $0.72^{* *}$ & & & $0.50^{*}$ & \\
\hline & $\mathrm{Al}$ & $0.59^{* *}$ & $0.61^{* *}$ & & & $0.82^{* *}$ & $0.45^{*}$ & & $0.51^{*}$ & \\
\hline & $\mathrm{Fe}$ & $0.64^{* *}$ & $0.80^{* *}$ & & & $0.67^{* *}$ & & & $0.46^{*}$ & \\
\hline \multirow{7}{*}{$\begin{array}{l}\text { ТСВ } \\
(n=18)\end{array}$} & $\mathrm{pH}$ & & & $-0.50^{*}$ & & & & & & \\
\hline & SM & $-0.47^{*}$ & $-0.49^{* *}$ & & & & & & & \\
\hline & Salinity & & $0.54^{* *}$ & $0.48^{*}$ & & & & & & \\
\hline & TOC & & & & & & & & & \\
\hline & $\mathrm{Ca}$ & $0.50^{*}$ & $0.79^{* *}$ & & $0.50^{*}$ & & $0.51^{* *}$ & $0.55^{*}$ & & \\
\hline & $\mathrm{Al}$ & $0.51^{*}$ & $0.83^{* *}$ & & $0.51^{*}$ & & $0.57^{* *}$ & $0.51^{*}$ & $0.55^{*}$ & \\
\hline & $\mathrm{Fe}$ & & & & & & & & & \\
\hline \multirow{7}{*}{$\begin{array}{l}\text { All } \\
(n=72)\end{array}$} & $\mathrm{pH}$ & $-0.48^{* *}$ & $-0.45^{* *}$ & $-0.60^{* *}$ & & $-0.50^{* *}$ & & & & $-0.41^{* *}$ \\
\hline & SM & & & & & & & $-0.28^{*}$ & & \\
\hline & Salinity & $0.76^{* *}$ & $0.69^{* *}$ & $0.61^{* *}$ & & $0.64^{* *}$ & & $-0.36^{* *}$ & & $0.43^{* *}$ \\
\hline & TOC & $0.63^{* *}$ & $0.65^{* *}$ & $0.62^{* *}$ & & $0.58^{* *}$ & & & & $0.34^{* *}$ \\
\hline & $\mathrm{Ca}$ & $0.75^{* *}$ & $0.74^{* *}$ & $0.60^{* *}$ & & $0.72^{* *}$ & & & & $0.36^{* *}$ \\
\hline & $\mathrm{Al}$ & $0.75^{* *}$ & $0.71^{* *}$ & $0.54^{* *}$ & & $0.73^{* *}$ & & & & $0.36^{* *}$ \\
\hline & $\mathrm{Fe}$ & $0.65^{* *}$ & $0.63^{* *}$ & $0.48^{* *}$ & & $0.63^{* *}$ & & & & $0.33^{* *}$ \\
\hline
\end{tabular}

${ }^{*}$ Significant at the 0.05 level (2-tailed).

${ }^{* *}$ Significant at the 0.01 level (2-tailed).

in alkaline soils, $\mathrm{P}$ fixation which is biologically unavailable in many wetlands is governed by the activities of $\mathrm{Ca}$ and $\mathrm{Mg}$ [2830]. We defined that forms of Bicarb- $\mathrm{P}_{\mathrm{i}}$ and $\mathrm{NaOH}-\mathrm{P}_{\mathrm{i}}$ in soils represent a continuum of $\mathrm{Fe}$ - and $\mathrm{Al}$-associated $\mathrm{P}$ extractable with high $\mathrm{pH}$ (8.7-9.2). Correlation and regression analyses showed that the amorphous and free Fe/Al oxides, in the newly formed wetland soils, were the crucial chemical factors ascribed to the soil $\mathrm{P}$ retention and release capacity [20].
Although the dilute extractable inorganic $\mathrm{P}$ has been clearly defined as Ca-associated P, D.HCl- $\mathrm{P}_{\mathrm{i}}$ was not correlated with soil geochemical properties in our study (Table 4). Meanwhile, no significant correlations were found between organic $\mathrm{P}$ fractions (Bicarb- $\mathrm{P}_{\mathrm{o}}, \mathrm{NaOH}-\mathrm{P}_{\mathrm{o}}$, and C.HCl- $\mathrm{P}_{\mathrm{o}}$ ) and soil geochemical properties. All of the above results indicated that the there were actually links between $\mathrm{P}$ forms in estuarine coastal soils and the intensity of plant salt tolerance. 
This appearance was attributed to the fact that the formation of newborn coastal wetland in the YRD is only 35 years (1976-2011). Meanwhile, the soils in the wetland were formed from sediment eroded from the upland soils on the Loess Plateau and deposited in the Yellow River estuary. Deposition is usually episodic rather than smoothly continuous and this newborn wetland is still also influenced by water coming from the Yellow River and ocean tide $[11,13]$.

3.4. Vegetation Effects on the P Forms for Tidal River Network Region. Plants growing on tidal wetland are exposed to a number of extreme conditions, such as high wind velocities, drastic temperature fluctuations, high potential evapotranspiration, salt spray, low levels of soil nutrients, and burial in sediment $[31,32]$. Vegetation has been proven to improve the soil $\mathrm{P}$ dynamics and availability [33-35]. Our results showed some clear differences between RB covered by Phragmites australis and TB covered by Suaeda heteroptera Kitag. (Table 2). The mean content of Resin-P, C.HCl- $\mathrm{P}_{\mathrm{i}}$, Residual-P, and total inorganic $\mathrm{P}$ of TB soils $\left(14.6 \mathrm{mg} \mathrm{kg}^{-1}, 73.8 \mathrm{mg} \mathrm{kg}^{-1}\right.$, $46.9 \mathrm{mg} \mathrm{kg}^{-1}$, and $570.2 \mathrm{mg} \mathrm{kg}^{-1}$, resp.) was higher than those of $\mathrm{RB}$ soils $\left(11.0 \mathrm{mg} \mathrm{kg}^{-1}, 61.6 \mathrm{mg} \mathrm{kg}^{-1}, 42.0 \mathrm{mg} \mathrm{kg}^{-1}\right.$, and $542.4 \mathrm{mg} \mathrm{kg}^{-1}$, resp.), while the mean content of Bicarb- $\mathrm{P}_{\mathrm{o}}$, $\mathrm{NaOH}-\mathrm{P}_{\mathrm{o}}$, and total organic $\mathrm{P}$ of $\mathrm{TB}$ soils $\left(17.7 \mathrm{mg} \mathrm{kg}^{-1}\right.$, $25.7 \mathrm{mg} \mathrm{kg}^{-1}$, and $66.1 \mathrm{mg} \mathrm{kg}^{-1}$, resp.) was less than those of $\mathrm{RB}$ soils (40.8 $\mathrm{mg} \mathrm{kg}^{-1}, 43.9 \mathrm{mg} \mathrm{kg}^{-1}$, and $106.7 \mathrm{mg} \mathrm{kg}^{-1}$, resp.). Furthermore, there was no significant difference in mean content of Bicarb- $\mathrm{P}_{\mathrm{i}}, \mathrm{NaOH}-\mathrm{P}_{\mathrm{i}}$, D.HCl- $\mathrm{P}_{\mathrm{i}}$, C.HCl- $\mathrm{P}_{\mathrm{o}}$, and total $\mathrm{P}$ of $\mathrm{TB}$ and $\mathrm{RB}$. Vegetation cover also influenced the correlation coefficients between above $\mathrm{P}_{\mathrm{i}}$ fractions and soil geochemical properties in the tidal river network region. The coefficients of RB covered by Phragmites australis and TB covered by Suaeda heteroptera Kitag. were higher than those of $\mathrm{BRB}$ and TCB with no vegetation cover. The results support the view that the soil $\mathrm{P}$ content varies with vegetation covers and have actually indicated links between the P forms in tidal wetland soils and the intensity of plant salt tolerance.

3.5. Hydrologic Disturbance Effects on the $P$ Forms for Tidal River Network Region. Disturbance and stress are not uniformly high within coastal systems but exhibit strong gradients in physical disturbance, water availability, soil $\mathrm{pH}$, nutrient level, and salinity [36]. Hydrology has been shown to influence a wetland soil ability to sorb [37, 38]. Berretta and Sansalone investigated the transport and partitioning of $\mathrm{P}$ to particulate matter fractions in runoff from a landscaped and biogenically loaded car park in Gainesville, FL (GNV), and found that $\mathrm{P}$ is predominantly bound to particulate matter (PM) fractions and the transport of each of PM and $\mathrm{P}$ fractions was influenced by separate hydrologic parameters [39]. Salinity was found to account for a significant proportion of variance in the phosphorus sorption index data [40]. Li et al. [15] simulated the effects of water level and salinity on nitrogen and phosphorus in salt marsh soils of the Yellow River Delta. Results showed that total nitrogen and total phosphorus contents accumulated in surface soils in each sampling date and that they are significantly affected by soil organic matter and salinity. Under such tidal-river conditions, water and salt of soil play a dominant role in the geochemical property in the area. In present research, it is also shown that SM and salinity significantly changed the phosphorus fractions in soils. Generally, the mean Resin-P, Bicarb- $\mathrm{P}_{\mathrm{i}} / \mathrm{P}_{\mathrm{o}}, \mathrm{NaOH}-\mathrm{P}_{\mathrm{i}} / \mathrm{P}_{\mathrm{o}}, \mathrm{C} . \mathrm{HCl}-\mathrm{P}_{\mathrm{i}}$, Residual-P, and total $\mathrm{P}_{\mathrm{i}} / \mathrm{P}_{\mathrm{t}}$ concentrations were TCB (seawater mainly influenced soil, higher value of SM and salinity) $\gg$ BRB (freshwater mainly influenced soil, lower value of SM and salinity) and there was no significant difference found in mean content of D.HCl- $\mathrm{P}_{\mathrm{i}}$, C.HCl- $\mathrm{P}_{\mathrm{o}}$, and total $\mathrm{P}_{\mathrm{o}}$ (Table 4). The results also support the view that the soil $\mathrm{P}$ availability can increase by increasing salinity [41-43].

\section{Conclusions}

Our results proved that the modified Hedley fraction was effective in differentiating inorganic and organic $\mathrm{P}$ forms in this tidal river network region. The phosphorus in the investigated region exists in many complex chemical forms, which differ markedly in profile distribution in the four sampling plots. The $\mathrm{P}_{\mathrm{t}}$ ranged from 612.1 to $657.8 \mathrm{mg} \mathrm{kg}^{-1}$. D.HCl- $\mathrm{P}_{\mathrm{i}}$ was the predominant form of total extracted $\mathrm{P}_{\mathrm{i}}$ and $\mathrm{NaOH}-\mathrm{P}_{\mathrm{o}}$ was the predominant form of total extracted $\mathrm{P}_{0}$, while Bicarb- $\mathrm{P}_{\mathrm{i}}$ and C.HCl- $\mathrm{P}_{\mathrm{o}}$ were the lowest fractions of total extracted $\mathrm{P}_{\mathrm{i}}$ and $\mathrm{P}_{\mathrm{o}}$, respectively, in all the $\mathrm{P}$ forms. The Pearson correlation matrix showed that Resin-P, Bicarb- $\mathrm{P}_{\mathrm{i}}$, $\mathrm{NaOH}-\mathrm{P}_{\mathrm{i}}$, and C.HCl- $\mathrm{P}_{\mathrm{i}}$ were strongly positively correlated with soil salinity, $\mathrm{TOC}, \mathrm{Ca}, \mathrm{Al}$, and $\mathrm{Fe}$, while all forms of organic $\mathrm{P}$ (Bicarb- $\mathrm{P}_{\mathrm{o}}, \mathrm{NaOH}-\mathrm{P}_{\mathrm{o}}$, and C.HCl- $\mathrm{P}_{\mathrm{o}}$ ) did not show any significant correlation with geochemical properties. Duncan multiple-range test indicated the $\mathrm{P}$ forms and distribution heterogeneity in the profiles can be attributed to the influences of different vegetation cover and hydrologic disturbance. The estimated distribution of different soil $\mathrm{P}$ fractions presented in the tidal river network region will be useful for wetland evolution that includes $\mathrm{P}$ as a limiting element in biological production by providing initial estimates of the available soil $\mathrm{P}$ for plant uptake and microbial utilization. Meanwhile, further investigation should be made to explore $\mathrm{P}$ availability and transformation dynamics in the soil under hydrologic disturbance.

\section{Conflict of Interests}

The authors declare that there is no conflict of interests regarding the publication of this paper.

\section{Acknowledgments}

The authors would like to thank the Project of National Science \& Technology Pillar Program in "12th Five Year" period (2011BAC02B01), National Natural Science Foundation for Distinguished Young Scholar of Shandong Province (no. JQ201114), and the CAS/SAFEA International Partnership Program for Creative Research Teams- "Representative environmental processes and resources effects in coastal zone." The authors also would like to thank the Yellow River Delta Wetland Ecological Experimental Station, CAS, for providing experimental and residential place for this study. 


\section{References}

[1] P. H. Doering, C. A. Oviatt, B. L. Nowicki, E. G. Klos, and L. W. Reed, "Phosphorus and nitrogen limitation of primary production in a simulated estuarine gradient," Marine Ecology Progress Series, vol. 124, no. 1-3, pp. 271-287, 1995.

[2] G. M. Pierzynski, G. F. Vance, and J. T. Sims, Soils and Environmental Quality, CRC Press, Boca Raton, Fla, USA, 2005.

[3] F. J. Stevenson and M. A. Cole, Cycles of Soils: Carbon, Nitrogen, Phosphorus, Sulfur, Micronutrients, John Wiley \& Sons, New York, 1999.

[4] E. T. Levy and W. H. Schlesinger, "A comparison of fractionation methods for forms of phosphorus in soils," Biogeochemistry, vol. 47, no. 1, pp. 25-38, 1999.

[5] M. R. Carter and E. G. Gregorich, Soil Sampling and Methods of Analysis, Taylor \& Francis, Boca Raton, Fla, USA, 2008.

[6] M. Li, J. Zhang, G. Q. Wang, H. J. Yang, M. J. Whelan, and S. M. White, "Organic phosphorus fractionation in wetland soil profiles by chemical extraction and phosphorus-31 nuclear magnetic resonance spectroscopy," Applied Geochemistry, vol. 33, pp. 213-221, 2013.

[7] M. J. Hedley, J. W. B. Stewart, and B. S. Chauhan, "Changes in inorganic and organic soil phosphorus fractions induced by cultivation practices and by laboratory incubations," Soil Science Society of America Journal, vol. 46, no. 5, pp. 970-976, 1982.

[8] A. F. Cross and W. H. Schlesinger, "A literature review and evaluation of the Hedley fractionation: applications to the biogeochemical cycle of soil phosphorus in natural ecosystems," Geoderma, vol. 64, no. 3-4, pp. 197-214, 1995.

[9] A. F. Cross and W. H. Schlesinger, "Biological and geochemical controls on phosphorus fractions in semiarid soils," Biogeochemistry, vol. 52, no. 2, pp. 155-172, 2001.

[10] G.-P. Wang, Z.-L. Zhai, J.-S. Liu, and J.-D. Wang, "Forms and profile distribution of soil phosphorus in four wetlands across gradients of sand desertification in Northeast China," Geoderma, vol. 145, no. 1-2, pp. 50-59, 2008.

[11] Q. Ye, S. Chen, Q. Chen et al., "Spatial-temporal characteristics in landscape evolution of the Yellow River Delta during 18552000 and a way out for the Yellow River estuary," Chinese Science Bulletin, vol. 51, pp. 197-209, 2006.

[12] J. D. Milliman and J. P. M. Syvitski, "Geomorphic/tectonic control of sediment discharge to the ocean: the importance of small mountainous rivers," The Journal of Geology, vol. 100, no. 5, pp. 525-544, 1992.

[13] J. Yu, Y. Fu, Y. Li et al., "Effects of water discharge and sediment load on evolution of modern Yellow River Delta, China, over the period from 1976 to 2009," Biogeosciences, vol. 8, no. 9, pp. 2427-2435, 2011.

[14] C. Song and G. Liu, "Application of remote sensing detection and gis in analysis of vegetation pattern dynamics in the Yellow River Delta," Chinese Journal of Population, Resources and Environment, vol. 6, no. 2, pp. 62-69, 2008.

[15] S.-N. Li, G.-X. Wang, W. Deng, Y.-M. Hu, and W.-W. Hu, "Influence of hydrology process on wetland landscape pattern: a case study in the Yellow River Delta," Ecological Engineering, vol. 35, no. 12, pp. 1719-1726, 2009.

[16] W. Ouyang, X. Wang, F. Hao, and R. Srinivasan, “Temporalspatial dynamics of vegetation variation on non-point source nutrient pollution," Ecological Modelling, vol. 220, no. 20, pp. 2702-2713, 2009.

[17] B. Cui, Q. Yang, Z. Yang, and K. Zhang, "Evaluating the ecological performance of wetland restoration in the Yellow
River Delta, China," Ecological Engineering, vol. 35, no. 7, pp. 1090-1103, 2009.

[18] H. Fan, H. Huang, and T. Zeng, "Impacts of anthropogenic activity on the recent evolution of the Huanghe (Yellow) River delta," Journal of Coastal Research, vol. 22, no. 4, pp. 919-929, 2006.

[19] L. L. Wang, M. Ye, Q. S. Li, H. Zou, and Y. S. Zhou, "Phosphorus speciation in wetland sediments of Zhujiang (Pearl) River Estuary, China,", Chinese Geographical Science, vol. 23, no. 5, pp. 574-583, 2013.

[20] G. Xu, H. B. Shao, J. N. Sun, and S. X. Chang, "Phosphorus fractions and profile distribution in newly formed wetland soils along a salinity gradient in the Yellow River Delta in China," Journal of Plant Nutrition and Soil Science, vol. 175, no. 5, pp. 721-728, 2012.

[21] G. Pan, M. D. Krom, M. Y. Zhang et al. et al., "Impact of suspended inorganic particles on phosphorus cycling in the Yellow River (China)," Environmental Science \& Technology, vol. 47, no. 17, pp. 9685-9692, 2013.

[22] J. N. Sun, G. Xu, H. B. Shao, and S. H. Xu, "Potential retention and release capacity of phosphorus in the newly formed wetland soils from the yellow river delta, China," Clean-Soil Air Water, vol. 40, no. 10, pp. 1131-1136, 2012.

[23] J. Murphy and J. P. Riley, "A modified single solution method for the determination of phosphate in natural waters," Analytica Chimica Acta, vol. 27, pp. 31-36, 1962.

[24] H. Tiessen and J. Q. Moir, "Characterization of available P by sequential extraction," in Soil Sampling and Methods of Analysis, pp. 293-306, Taylor \& Francis, Boca Raton, Fla, USA, 2008.

[25] J. Yu, X. Chen, Z. Sun et al., "The spatial distribution characteristics of soil nutrients in new-born coastal wetland in the Yellow River delta," Acta Scientiae Circumstantiae, vol. 30, no. 4, pp. 855-861, 2010.

[26] S. Verma, S. K. Subehia, and S. P. Sharma, "Phosphorus fractions in an acid soil continuously fertilized with mineral and organic fertilizers," Biology and Fertility of Soils, vol. 41, no. 4, pp. 295300, 2005.

[27] A. Mishra, J. K. Tripathi, P. Mehta, and V. Rajamani, "Phosphorus distribution and fractionation during weathering of amphibolites and gneisses in different climatic setups of the Kaveri river catchment, India," Applied Geochemistry, vol. 33, pp. 173-181, 2013.

[28] R. E. Masto, M. Mahato, V. A. Selvi, and L. C. Ram, “The effect of fly ash application on phosphorus availability in an acid soil," Energy Sources A: Recovery Utilization and Environmental Effects, vol. 35, no. 23, pp. 2274-2283, 2013.

[29] D. M. Paiva, C. L. Walk, and A. P. McElroy, "Influence of dietary calcium level, calcium source, and phytase on bird performance and mineral digestibility during a natural necrotic enteritis episode," Poultry Science, vol. 92, no. 12, pp. 3125-3133, 2013.

[30] M. C. W. M. Wadu, V. K. Michaelis, S. Kroeker, and O. O. Akinremi, "Exchangeable calcium/magnesium ratio affects phosphorus behavior in calcareous soils,", Soil Science Society of America Journal, vol. 77, no. 6, pp. 2004-2013, 2013.

[31] M. A. Maun, "Adaptations of plants to burial in coastal sand dunes," Canadian Journal of Botany, vol. 76, no. 5, pp. 713-738, 1998.

[32] Z. Sun, X. Mou, G. Lin, L. Wang, H. Song, and H. Jiang, "Effects of sediment burial disturbance on seedling survival and growth of Suaeda salsa in the tidal wetland of the Yellow River estuary," Plant and Soil, vol. 337, no. 1, pp. 457-468, 2010. 
[33] N. C. Tuchman, D. J. Larkin, P. Geddes, R. Wildova, K. Jankowski, and D. E. Goldberg, "Patterns of environmental change associated withTypha xglauca invasion in a Great Lakes coastal wetland," Wetlands, vol. 29, no. 3, pp. 964-975, 2009.

[34] K. M. B. Boomer and B. L. Bedford, "Groundwater-induced redox-gradients control soil properties and phosphorus availability across four headwater wetlands, New York, USA," Biogeochemistry, vol. 90, no. 3, pp. 259-274, 2008.

[35] G. Bonanomi, M. Rietkerk, S. C. Dekker, and S. Mazzoleni, "Islands of fertility induce co-occurring negative and positive plant-soil feedbacks promoting coexistence," Plant Ecology, vol. 197, no. 2, pp. 207-218, 2008.

[36] E. Balestri and C. Lardicci, "The impact of physical disturbance and increased sand burial on clonal growth and spatial colonization of Sporobolus virginicus in a coastal dune system," PLoS ONE, vol. 8, no. 8, Article ID e72598, 2013.

[37] J. R. Axt and M. R. Walbridge, "Phosphate removal capacity of palustrine forested wetlands and adjacent uplands in Virginia," Soil Science Society of America Journal, vol. 63, no. 4, pp. 10191031, 1999.

[38] R. M. Chambers and W. E. Odum, "Porewater oxidation, dissolved phosphate and the iron curtain: iron-phosphorus relations in tidal freshwater marshes," Biogeochemistry, vol. 10, no. 1, pp. 37-52, 1990.

[39] C. Berretta and J. Sansalone, "Hydrologic transport and partitioning of phosphorus fractions," Journal of Hydrology, vol. 403, no. 1-2, pp. 25-36, 2011.

[40] G. L. Bruland and G. DeMent, "Phosphorus sorption dynamics of hawaii's coastal wetlands," Estuaries and Coasts, vol. 32, no. 5, pp. 844-854, 2009.

[41] L. E. Fox, S. L. Sager, and S. C. Wofsy, "The chemical control of soluble phosphorus in the Amazon estuary," Geochimica et Cosmochimica Acta, vol. 50, no. 5, pp. 783-794, 1986.

[42] W. A. House, "The physico-chemical conditions for the precipitation of phosphate with calcium," Environmental Technology, vol. 20, no. 7, pp. 727-733, 1999.

[43] P. V. Sundareshwar and J. T. Morris, "Phosphorus sorption characteristics of intertidal marsh sediments along an estuarine salinity gradient," Limnology and Oceanography, vol. 44, no. 7, pp. 1693-1701, 1999. 

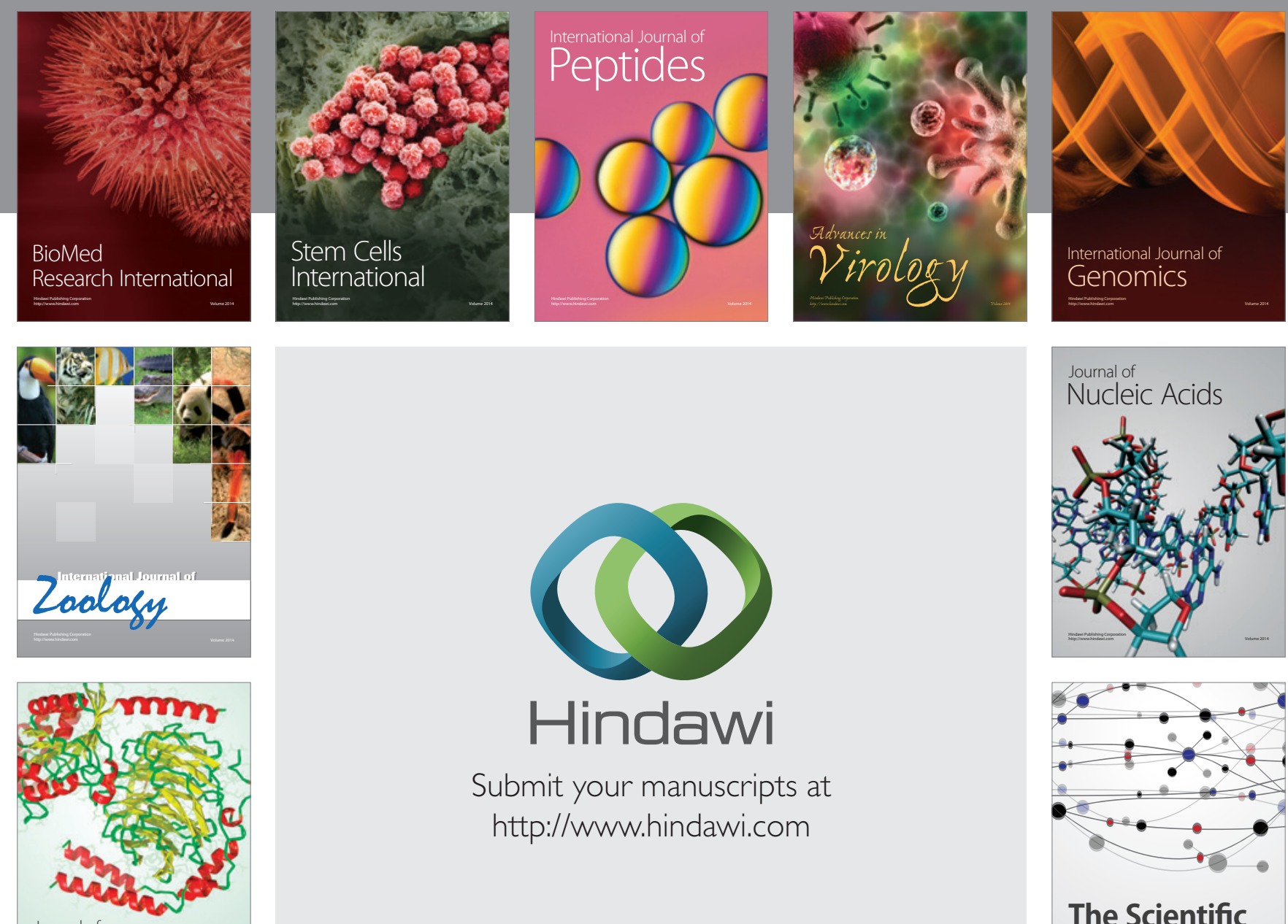

Submit your manuscripts at

http://www.hindawi.com

Journal of
Signal Transduction
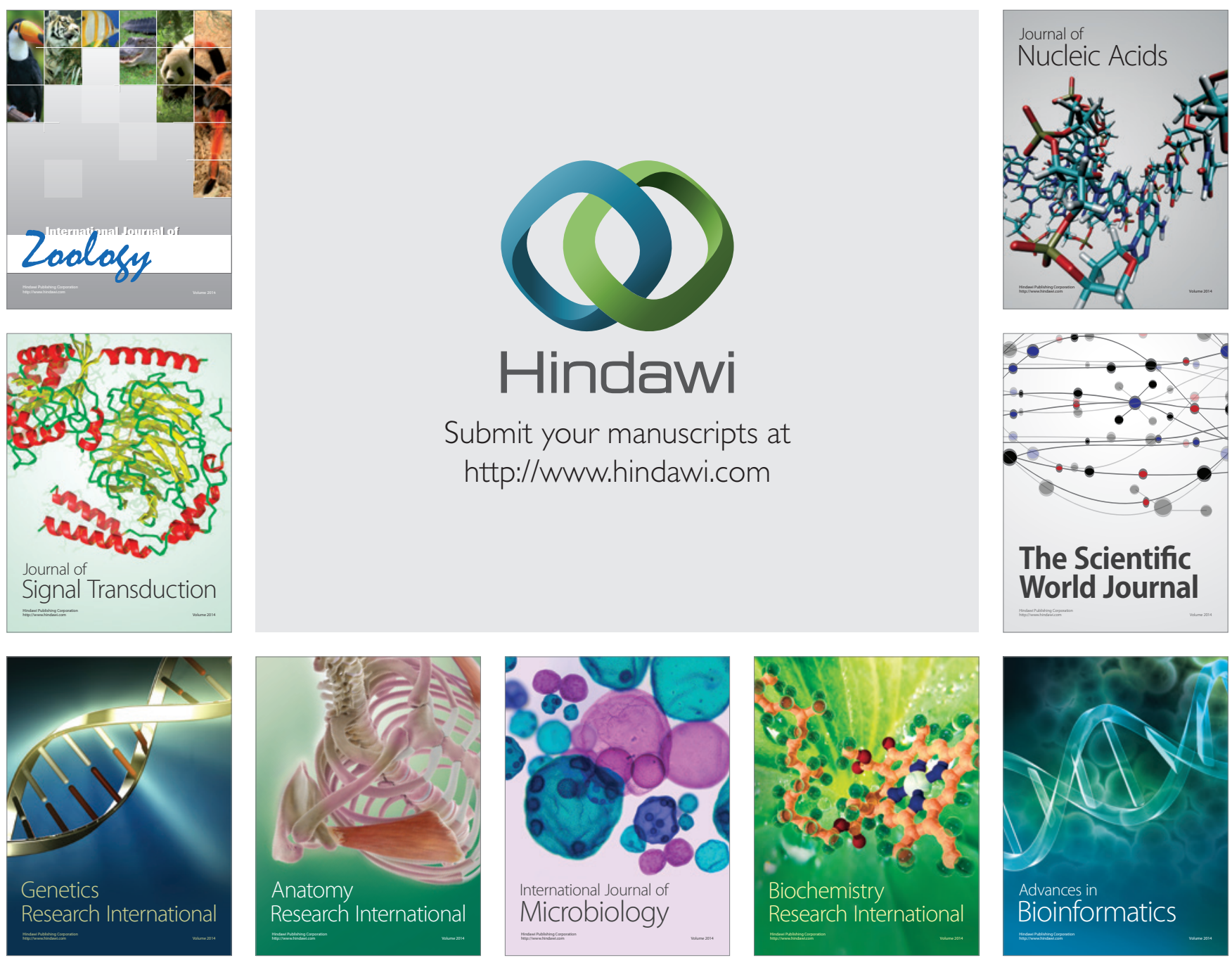

The Scientific World Journal
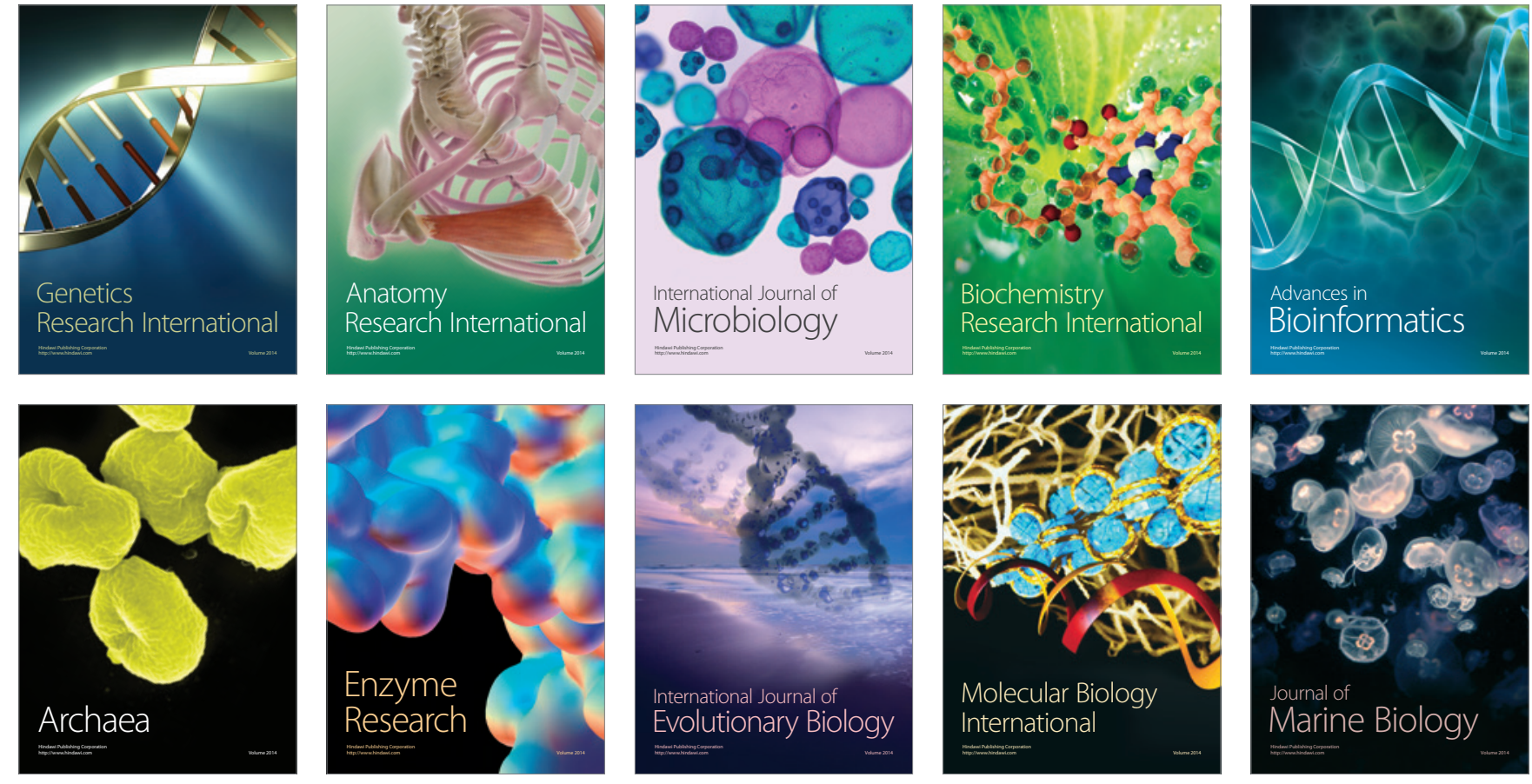